\title{
Sequential anode-cathode configuration improves cathodic oxygen reduction and effluent quality of microbial fuel cells
}

\author{
Stefano Freguia ${ }^{1}$, Korneel Rabaey ${ }^{2}$, Zhiguo Yuan ${ }^{3}$, Jürg Keller* \\ Advanced Water Management Centre, The University of Queensland, St. Lucia, QLD 4072, Australia
}

\section{A R T I C L E I N F O}

Article history:

Received 25 June 2007

Received in revised form

3 October 2007

Accepted 6 October 2007

Available online 11 October 2007

Keywords:

Biocatalysis

Biofuel cell

Cathodic biofilm

Oxygen reduction

\begin{abstract}
A B S T R A C T
The reduction of oxygen at the cathode and the diffusion of protons from the anode to the cathode are currently perceived as two major bottlenecks of microbial fuel cells (MFCs). To address these issues, we have designed an MFC configuration in which the effluent of an acetate-fed anode was used as a feed for an aerated, biocatalysed cathode. The development of a cathodic biofilm achieved a four-fold increase of the current output compared with the non-catalysed graphite cathode, while the $\mathrm{pH}$ variation in the cathode compartment was reduced due to the additional transfer of protons via the liquid stream. The sequential anode-cathode configuration also provided for chemical oxygen demand (COD) polishing at the cathode by heterotrophic bacteria, with overall acetate removal consistently greater than $99 \%$. The anode achieved an organic substrate removal of up to $2.45 \mathrm{~kg} \mathrm{COD} / \mathrm{m}^{3}$ of anode liquid volume per day, at Coulombic efficiencies of $65-95 \%$. Electron balances at the cathode revealed that the main cathodic process was oxygen reduction to water with no significant Coulombic losses. The maximal power output during polarization was $110 \mathrm{~W} / \mathrm{m}^{3}$ cathode liquid volume. The process could be operated in a stable way during more than 9 months of continuous operation. Excessive organic loading to the cathode should be avoided as it can reduce the long-term performance through the growth of heterotrophic bacteria.
\end{abstract}

c 2007 Elsevier Ltd. All rights reserved.

\section{Introduction}

Microbial fuel cells (MFCs) are fuel cells in which electron donors, such as organic materials in wastewater, are oxidized at an electrode (anode) by bacteria mostly growing as a biofilm on the anode surface (Allen and Bennetto, 1993; Rabaey and Verstraete, 2005). These anodophilic bacteria take up organic substrate and gain energy for growth and cell maintenance from the transfer of electrons from a substrate at low redox potential to an anode at higher potential. The ability of MFCs to generate electrical power while oxidizing organic material to $\mathrm{CO}_{2}$ has raised interest in this process as a sustainable technology for wastewater treatment. Indeed, it can be calculated that the power generated by the oxidation of organics in a typical domestic wastewater is at least sufficient to cover the energy demand of a typical wastewater treatment plant, which is around $0.5 \mathrm{kWh} / \mathrm{m}^{3}$ (Rabaey and Verstraete, 2005).

Like in conventional fuel cells, anodic oxidation is accompanied by a reduction at a second electrode (cathode) enclosed in a separate compartment. Electrons are transferred from anode to cathode through an external electrical

\footnotetext{
${ }^{*}$ Corresponding author. Tel.: +6173365 4727; fax: +6173365 4726.

E-mail addresses: stefano@awmc.uq.edu.au (S. Freguia), k.rabaey@awmc.uq.edu.au (K. Rabaey), zhiguo@awmc.uq.edu.au (Z. Yuan), j.keller@awmc.uq.edu.au (J. Keller).

${ }^{1}$ Tel.: +61 733654729 ; fax: +61733654726.

${ }^{2}$ Tel.: +6173365 7519; fax: +61733654726.

3 Tel.: +6173365 4374; fax: +61733654726 .
}

0043-1354/\$- see front matter (c) 2007 Elsevier Ltd. All rights reserved.

doi:10.1016/j.watres.2007.10.007 
circuit, containing a resistor or power user. In order to close the circuit and maintain electroneutrality in the anodic and cathodic compartments, protons and other cations are allowed to transfer from anode to cathode through a cation exchange membrane (CEM).

A multitude of electron acceptors have been used at MFC cathodes. Potassium hexacyanoferrate $\left(\mathrm{K}_{3} \mathrm{Fe}(\mathrm{CN})_{6}\right)$ has been used in laboratory studies due to its ability to provide a constant cathodic potential (Logan et al., 2006). Nitrate can be reduced to $\mathrm{N}_{2}$ in biocatalysed cathodes (Clauwaert et al., 2007), which enable removal of this nutrient aside from the anode-associated organic carbon removal. For energy generation, oxygen is the preferred electron acceptor due to its abundant availability and high redox potential (Zhao et al., 2006). MFCs that use oxygen as electron acceptor suffer from some severe limitations: (1) the high cathodic overpotential (i.e. drop of cathodic potential due to the activation energy of the reaction) of oxygen reduction at the cathode limits the energetic efficiency (Zhao et al., 2006); (2) the inability of any currently available CEM to selectively transfer protons (Rozendal et al., 2006) causes a $\mathrm{pH}$ gradient, acidic at the anode and alkaline at the cathode (due to the fact that one proton is produced/ consumed per electron transferred, respectively), reducing the thermodynamic potential difference between anode and cathode and causing an inhibition of anodophiles (Rabaey et al., 2003); (3) due to the incomplete chemical oxygen demand (COD) removal often experienced at the anodes (Liu et al., 2004), the addition of an extra polishing step downstream of the MFC anode is required. The high cathodic overpotential of $\mathrm{O}_{2}$ reduction on graphite can be reduced by the use of chemical catalysts, such as platinum (Cheng et al., 2006), transition metal porphyrins and phtalocyanines (Zhao et al., 2005) and ferric ions at low pH (Ter Heijne et al., 2006). Many of these catalysts are expensive and subject to poisoning. Catalysis of cathodic oxygen reduction by biofilms has also been observed. He and Angenent (2006) reviewed several possible biological cathodic processes, which included the reduction of oxygen. Bergel et al. (2005) described a fuel cell where a seawater biofilm growing on a stainless-steel cathode was able to catalyse the reduction of oxygen, using the electrons delivered by the cathode.

The inability of conventional CEMs to transfer protons selectively has been addressed by some researchers with the complete removal of the membrane (Liu and Logan, 2004). However, this solution to reduce the $\mathrm{pH}$ gradient comes at the price of a low Coulombic efficiency (as low as 12\%), due to direct oxidation of the substrate by oxygen.

In this paper, we introduce a new configuration for oxygen-cathode MFCs, which is able to overcome several of the current limitations of MFCs. This configuration is based on the use of the anode effluent as a continuous feed for the cathode. This strategy provides an additional transport of protons from the anode to the cathode. It also transfers the remaining organics from the anode compartment to the aerated cathode compartment for further polishing. Lastly, it appears to drastically improve the development of an oxygen-reducing biofilm at the cathode.

\section{Materials and methods}

\subsection{Microbial fuel cells (MFCs)}

Two identical double-chamber MFCs (named here MFC-1 and MFC-2) built in rectangular geometry as depicted in Fig. 1A were used for the experiments. During the enrichment phase, the two MFCs were operated with identical configurations and feeding regimes to determine the reproducibility of the results. The volume of both the anodic and cathodic compartments was $480 \mathrm{~cm}^{3}$ each. Approximately $75 \%$ of the empty volume in each compartment was filled with granular graphite (El Carb 100, Graphite Sales, Inc., USA). The remaining $25 \%$ was used as headspace. The granules were $2-6 \mathrm{~mm}$ in

A

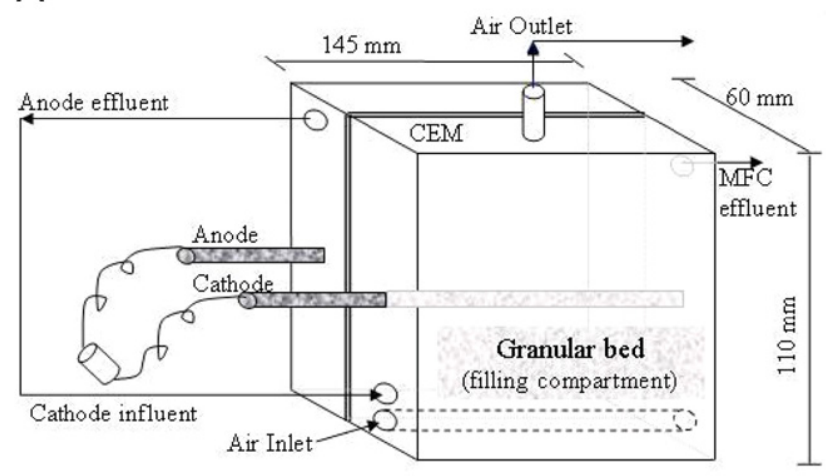

B

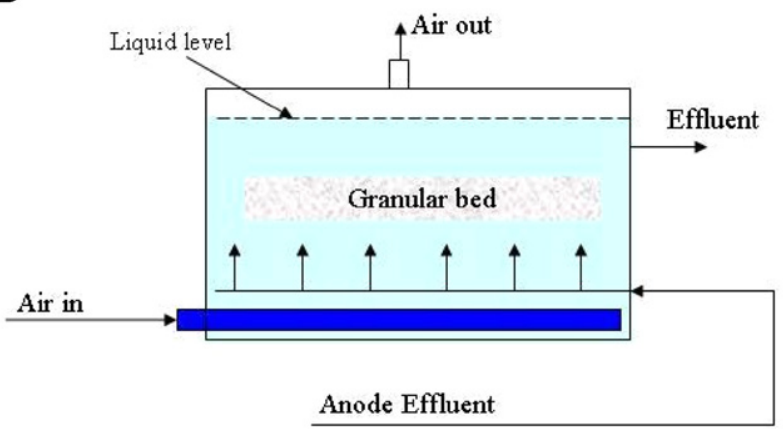

C

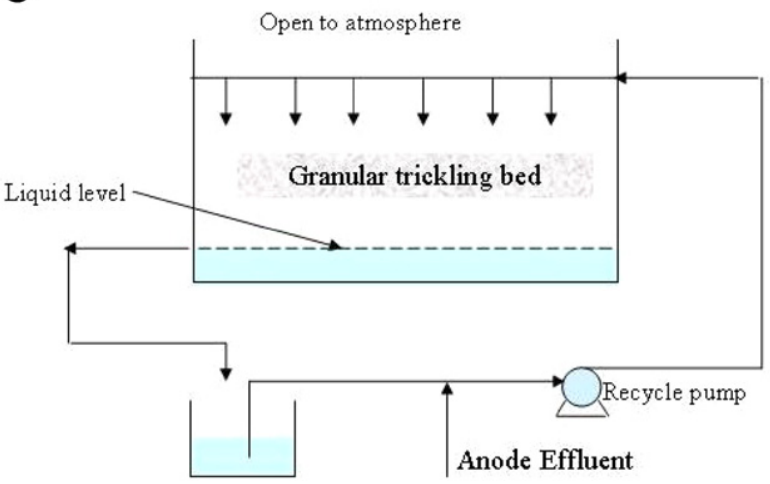

Fig. 1 - (A) Microbial fuel cell schematics with reactor sizes; (B) cathode with active aeration in a sequential anode-cathode MFC; (C) trickling bed cathode with passive aeration in a sequential anode-cathode MFC. 
diameter and had a porosity of $48 \%$, leaving a liquid volume of $173 \mathrm{~cm}^{3}\left(480 \mathrm{~cm}^{3} \times 0.75 \times 0.48\right)$ inside each compartment. The graphite granules had a nominal surface area of $500 \mathrm{~m}^{2} / \mathrm{m}^{3}$ (calculated assuming that the granules are spheres of $5 \mathrm{~mm}$ diameter) and a total surface area of $6.24 \times 10^{6} \mathrm{~m}^{2} / \mathrm{m}^{3}$, as measured by mercury porosimetry with the method of Favas and Jackson (2003). The surface area that could potentially be colonized by bacteria was taken as the area of the pores larger than $0.8 \mu \mathrm{m}$ according to the study of Kirchmann and Gerzabek (1999), giving $7.11 \times 10^{4} \mathrm{~m}^{2} / \mathrm{m}^{3}$. At the anode, the granular bed served as biofilm support and conducting bed, conveying electrons to a graphite rod. At the cathode, the graphite carried electrons to the final electron acceptor, which in this study was oxygen, supplied either by forcing air into the compartment with an aquarium pump and sparger (Fig. 1B) or by operating the cathode as a trickling bed open to the atmosphere (Fig. 1C). The anodic and cathodic rods were connected through an external resistor, which during continuous operation was kept at a resistance of 10 or $5 \Omega$. Two Ag/AgCl reference electrodes (Ref. 201, Radiometer Analytical) were placed in the anodic and cathodic compartments of each cell and connected to the respective electrodes, for measurements of half-cell potentials. The CEM was made of Ultrex (CMI-7000, Membranes International, USA). The anodic medium was recirculated at a rate of approximately $100 \mathrm{~mL} / \mathrm{min}$ in order to maintain well-mixed conditions and to avoid concentration gradients and clogging of the granular matrix. At the cathode, mixing was provided by the aeration bubbles when air was actively sparged into the compartment; when passive aeration was used, the catholyte was recirculated at a range of speeds $(30-120 \mathrm{~mL} / \mathrm{h})$ in order to avoid concentration gradients and maintain liquid continuity throughout the granular matrix. The reactors and the related tubing were thoroughly wrapped in aluminium foil to exclude light and thus avoid unwanted photobioreactions. The reactor was operated at a room temperature of $22 \pm 1{ }^{\circ} \mathrm{C}$. The anolyte consisted of modified M9-buffered medium ( $\mathrm{pH}$ 7.1) with the

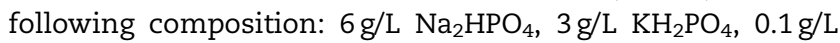
$\mathrm{NH}_{4} \mathrm{Cl}, 0.5 \mathrm{~g} / \mathrm{L} \mathrm{NaCl}, 0.1 \mathrm{~g} / \mathrm{L} \mathrm{MgSO}_{4} \cdot 7 \mathrm{H}_{2} \mathrm{O}, 15 \mathrm{mg} / \mathrm{L} \mathrm{CaCl}{ }_{2} \cdot 2 \mathrm{H}_{2} \mathrm{O}$ and $1.0 \mathrm{~mL} / \mathrm{L}$ of a trace elements solution as described previously (Rabaey et al., 2005). During normal operation, acetate was added to the medium to a concentration of $469 \mathrm{mg}$ acetic acid/L (500 mg COD/L). The anode was continuously fed at an influent flow rate of $25 \mathrm{~mL} / \mathrm{h}$, giving an organic loading of $1.7 \mathrm{~kg}$ CoD $/ \mathrm{m}^{3} \mathrm{~d}$ (in this study the loading rates are normalized to anode liquid volume). The anode effluent was entirely used as feed for the cathode in a sequential fashion as depicted in Fig. 1.

\subsection{Calculations and analysis}

COD removal, Coulombic efficiency and energy efficiency were calculated as described previously (Logan et al., 2006). The charge transferred to the circuit over time was calculated by integrating the current with respect to time. Liquid samples from the MFC anode and cathode compartments were filtered through a $0.22 \mu \mathrm{m}$ sterile filter and analysed for volatile fatty acids (VFAs) and for ammonium-nitrogen $\left(\mathrm{NH}_{4}^{+}-\mathrm{N}\right)$. VFA analysis was performed as described previously (Freguia et al., 2007b). $\mathrm{NH}_{4}^{+}-\mathrm{N}$ was analysed with a Lachat
Quik-Chem8000 Flow Injection Analyser. Soluble COD was determined using the dichromate method (Greenberg et al., 1992).

\subsection{Effect of loading rate}

After the establishment of a stable voltage under continuous operation with active aeration, the two MFCs (running with active aeration) were exposed to a range of organic loadings by varying either the feed concentration or the feed flow rate. High influent concentration experiments were conducted by doubling the feed acetate concentration to $938 \mathrm{mg} / \mathrm{L}$ acetic acid $(1000 \mathrm{mg} / \mathrm{L} \mathrm{COD})$; high feed rate experiments were done by increasing the flow rate up to $55 \mathrm{~mL} / \mathrm{h}$. These test conditions generated a range of organic loading rates between 1.7 and $3.9 \mathrm{~kg} \mathrm{COD} / \mathrm{m}^{3} \mathrm{~d}$. The effect of loading rate on MFC performance was evaluated by monitoring current, Coulombic efficiency and cathodic potential. Liquid samples were taken daily for acetate and COD measurements.

\subsection{Electrochemical monitoring}

The anode and cathode of each MFC were connected to an Agilent 34970A data acquisition unit. Voltage data were collected every $20 \mathrm{~s}$. The $\mathrm{Ag} / \mathrm{AgCl}$ reference electrodes were also connected to the instrument. The reading of the potential differences between reference electrodes and operating electrodes was a measurement of anodic and cathodic half-cell potentials. Polarization curves were generated during the continuous feeding regime using a potentiostat (VMP3 multichannel potentiostat, Princeton Applied Research, USA). The MFC was first operated in open circuit for $2 \mathrm{~h}$ to achieve a steady open-circuit voltage and subsequently the MFC voltage was varied with the potentiostat at a scan rate of $0.1 \mathrm{mV} / \mathrm{s}$.

\subsection{Electron balances}

Electron sources and sinks were measured both at the anode and at the cathode during continuous feeding with active aeration mode, to determine whether oxygen reduction to water is a complete representation of the cathodic process. The Titration and Off-gas Analysis (TOGA) sensor system as developed by Pratt et al. (2003) was used to determine the oxygen uptake rate (OUR) at the cathode of one of the reactors described above (MFC-1). The TOGA sensor allows mass balances to be determined on gas species by sending a gas with a known composition and flow rate through the reactor and monitoring the off-gas composition and flow rate with a mass spectrometer (Omnistar, Balzers AG, Liechtenstein). An oxygen-containing gas $\left(50 \% \mathrm{O}_{2}\right.$, $46.5 \% \mathrm{Ar}, 3.0 \% \mathrm{~N}_{2}, 0.5 \% \mathrm{CO}_{2}$ ) was bubbled through the cathode at a flow rate of $60 \mathrm{~mL} / \mathrm{min}$, while the MFC was run in continuous mode at the loading rate of $1.7 \mathrm{~kg}$ CoD $/ \mathrm{m}^{3} \mathrm{~d}$. The measurement of the off-gas flow and composition enabled the calculation of the oxygen uptake rate $\left(\mathrm{mmol}_{\mathrm{O}_{2}} / \mathrm{h}\right)$. Hourly liquid samples of anolyte and catholyte for acetate analysis were taken at least three times for each reported value to evaluate the statistical variability of the data. The measurements were used to calculate the cathode electron balance, 
given by

$0=4 \mathrm{OUR}-\frac{3600 \mathrm{I}}{\mathrm{F}}-8 \Delta \mathrm{Ac}_{\mathrm{C}}\left(1-\mathrm{Y}_{\mathrm{c}, \mathrm{h}}\right)$,

where I is the current $(\mathrm{mA}), \mathrm{F}$ the Faraday constant $(96,485 \mathrm{C} / \mathrm{mol})$, $\Delta \mathrm{Ac}_{\mathrm{C}}$ is the acetate consumption at the cathode (mmol acetate/h) and $Y_{c, h}$ is the heterotrophic growth yield at the cathode: a value of $0.53 \mathrm{gCOD}_{\text {biomass }} / \mathrm{gCOD}_{\text {acetate }}$ was assumed, based on the work of Heijnen (1999). Eq. (1) does not contain a loss term due to diffusion of oxygen to the cathode, because it can be calculated from previously reported results (Kim et al., 2007) that $\mathrm{O}_{2}$ diffusion through an Ultrex CEM is negligible at the conditions of these tests $\left(K_{\mathrm{L}}=9 \times 10^{-4} \mathrm{~cm} / \mathrm{s}\right.$, membrane surface $=158 \mathrm{~cm}^{2}$ ). To close overall electron balances over the whole MFC, the anode electron balance was also calculated (Eq. (2)). As revealed by a previous study (Freguia et al., 2007b), the only electron sinks of an MFC anode fed only with acetate are current and bacterial growth.

$0=\frac{3600 I}{F}-8 \Delta A c_{A}\left(1-Y_{a}\right)$.

In this case, $\Delta \mathrm{Ac}_{\mathrm{A}}$ is the acetate consumption at the anode $\left(\mathrm{mmol}_{\mathrm{AC}} / \mathrm{h}\right)$ and $\mathrm{Y}_{\mathrm{a}}$ is the anodic growth yield

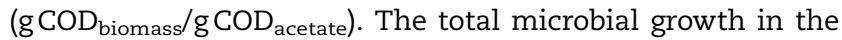
MFC was calculated via a nitrogen balance, assuming that the only sink of $\mathrm{N}$ is biomass growth. The molar $\mathrm{N}: \mathrm{C}$ ratio of anodophilic biomass is 0.18 and the biomass has a degree of reduction of $4.17 \mathrm{mmol} \mathrm{e}^{-} \mathrm{C}-\mathrm{mmol}$, from the biomass formula $\left(\mathrm{CH}_{1.75} \mathrm{O}_{0.52} \mathrm{~N}_{0.18}\right)$, measured by elemental analysis in a previous study (Freguia et al., 2007b).

$\Delta\left(\mathrm{NH}_{4}^{+}-\mathrm{N}\right)=8\left(\Delta \mathrm{Ac}_{\mathrm{A}} \mathrm{Y}_{\mathrm{a}}+\Delta \mathrm{Ac}_{\mathrm{C}} \mathrm{Y}_{\mathrm{c}, \mathrm{h}}\right) \frac{0.18}{4.17}$

where $\Delta\left(\mathrm{NH}_{4}^{+}-\mathrm{N}\right)$ is the difference in ammonium-nitrogen flow $(\mathrm{mmolN} / \mathrm{h}$ ) between anode influent and cathode effluent. Eq. (3) was used to determine the value of $Y_{a}$ to be used in Eq. (2). Samples for determination of acetate and ammonium were taken every hour during the tests, and Eqs. (1) and (2) were integrated over $1 \mathrm{~h}$ to obtain hourly average values. The hourly measurements were repeated three times to determine the statistical significance of the results.

\section{Results}

\subsection{Development of cathodic bio-catalysis}

Operation of a MFC with a non-catalysed oxygen cathode (MFC-1, operated at $10 \Omega$, influent COD of $500 \mathrm{mg} / \mathrm{L}$ and feed rate of $25 \mathrm{~mL} / \mathrm{h}$ ) produced a current of $14.9 \pm 1.9 \mathrm{~mA}$ (Freguia et al., 2007a). Following sequential connection of anode and cathode an increase in cathode performance occurred. The development of a cathodic biocatalysis typically started 5-10 days after the anode effluent of an MFC running with a noncatalysed oxygen cathode was connected to the cathode. The development was revealed by an increase of the current and cathodic potential. This development is shown for MFC-1 in Fig. 2, where it can be seen that the current increased by $80 \%$ between days 5 and 7 following connection of the anode effluent to the cathode. In the same time frame it can be seen that the acetate in the cathode effluent was reduced from 30 to $<5 \mathrm{mg} / \mathrm{L}$, suggesting that heterotrophic bacteria were also growing at the cathode. The current increase could be maintained for at least 9 months after the growth first occurred. The second reactor (MFC-2) that was connected in the same fashion gave similar results, with the current increasing from 16 to $27 \mathrm{~mA}$ in the time frame from 10 to 14 days after sequential connection.

\subsection{Performance of MFCs with active aeration}

During long-term continuous operation (the reactors have displayed stable performance for at least 9 months), the performance of the two sequential anode-cathode MFCs with direct air sparging was monitored and is summarized in Table 1, where each value was averaged from measurements over at least 3 days. The first MFC (MFC-1) was

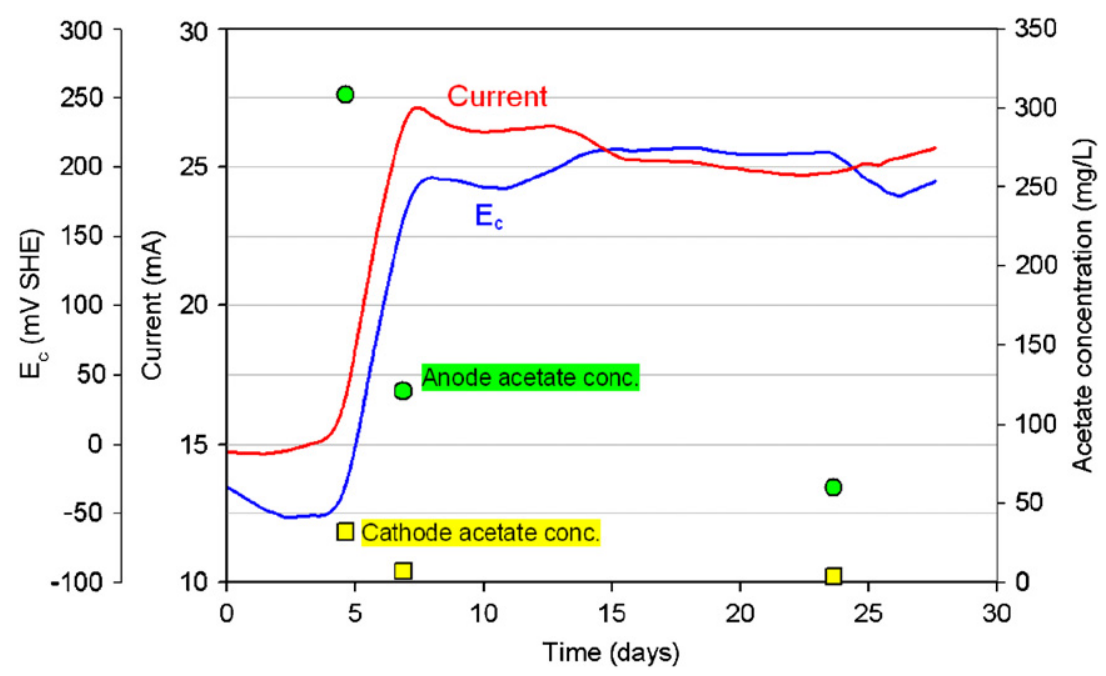

Fig. 2 - Development of current and cathodic potential (solid lines) and acetate concentrations at the anode (circles, $\bullet$ ) and cathode (squares, $\square$ ) following the connection of the anode effluent to the cathode (time zero) in an MFC run at $10 \Omega$ external resistance and acetate loading rate of $1.7 \mathrm{~kg}_{\mathrm{COD}} / \mathrm{m}^{3} \mathrm{~d}\left(500 \mathrm{mg}_{\mathrm{COD}} / \mathrm{L}\right)$. 
Table 1 - Summary of performance parameters for two sequential anode-cathode MFCs fed with acetate (500 mgcoD/L)

\begin{tabular}{lccc}
\hline & MFC-1 & \multicolumn{2}{c}{ MFC-2 } \\
\hline Loading rate $\left(\mathrm{kgcoD} / \mathrm{m}^{3} \mathrm{~d}\right)$ & 1.7 & 2.1 & 3.9 \\
$\mathrm{R}(\Omega)$ & 10 & 10 & 5 \\
Current $(\mathrm{mA})$ & 28.5 & $29.8 \pm 2.1$ & $56.9 \pm 1.1$ \\
Power density $\left(\mathrm{W} / \mathrm{m}^{3}\right)$ & 49.3 & $54.0 \pm 0.0$ & $106.0 \pm 0.0$ \\
COD anode $(\mathrm{mg} / \mathrm{L})$ & 136 & $29 \pm 2$ & $192 \pm 8$ \\
COD cathode $(\mathrm{mg} / \mathrm{L})$ & 35 & $21 \pm 1$ & $28 \pm 1$ \\
Acetate anode $(\mathrm{mg} / \mathrm{cod} / \mathrm{L})$ & 126 & 0 & $174.7 \pm 4.4$ \\
Acetate cathode $(\mathrm{mgco} / \mathrm{L})$ & 4 & 0 & 0 \\
Coulombic efficiency $(\%)$ & 72.1 & $61.8 \pm 4.3$ & $95.5 \pm 1.8$ \\
Energy efficiency $(\%)$ & 13.9 & $16.3 \pm 0.0$ & $16.9 \pm 0.0$ \\
pH anode & 6.2 & $5.79 \pm 0.06$ & $6.18 \pm 0.03$ \\
pH cathode & 7.2 & $7.16 \pm 0.06$ & $7.32 \pm 0.03$ \\
\end{tabular}

Power density normalized to cathode liquid volume.

operated at a loading rate of $1.7 \mathrm{~kg} \mathrm{CoD} / \mathrm{m}^{3} \mathrm{~d}$ and $10 \Omega$. Its performance was limited to a current of $28.5 \mathrm{~mA}$ and a power density of $49.3 \mathrm{~W} / \mathrm{m}^{3}$ of cathode liquid volume (equivalent to $11.8 \mathrm{~W} / \mathrm{m}^{3}$ of total reactor volume). The cathode liquid volume used here to normalize power is only the volume required to cover the cathode granules and as such represents the active volume where the reaction can occur. Unless otherwise stated, this will be the volume used to normalize power in this work. The second MFC (MFC-2) instead developed a stronger cathode that was able to maintain a current of up to $56.9 \mathrm{~mA}$ and a power density of $106.0 \mathrm{~W} / \mathrm{m}^{3}$ at a loading rate of $3.9 \mathrm{~kg} \mathrm{COD} / \mathrm{m}^{3} \mathrm{~d}$. This represents a nearly four-fold current increase compared with the abiotic cathode. Overall acetate removal was complete or nearly complete in all cases and the Coulombic efficiency (calculated based on the anodic acetate removal) ranged from $65 \%$ to $95 \%$. The energetic efficiency reached $16.9 \%$, which is higher than most values achieved for other oxygen cathode MFCs (Freguia et al., 2007a). From a comparison of acetate and COD measurements, it appears that $10-30 \mathrm{mg} / \mathrm{L}$ of soluble COD other than acetate was present in both anode and cathode effluents, probably consisting of soluble microbial products such as polypeptides and polysaccharides. The cathodic $\mathrm{pH}$ was stable at around 7.1-7.3, indicating that the sequential anode-cathode strategy is a successful way to avoid increasing catholyte $\mathrm{pH}$.

Peak performance was determined by polarization curves and power curves. The forward and backward curves shown in Fig. 3 were generated for MFC-2 at $3.9 \mathrm{~kg} \mathrm{COD} / \mathrm{m}^{3} \mathrm{~d}$ (influent COD of $500 \mathrm{mg} / \mathrm{L}$ and influent flow rate of $55 \mathrm{~mL} / \mathrm{h}$ ) and were compared with the respective curves generated with the same reactor with a control abiotic air cathode as described previously (Freguia et al., 2007a). They reveal an open circuit voltage of $805 \mathrm{mV}$, a short-circuit current of $71 \mathrm{~mA}$ and a maximum power of $110 \mathrm{~W} / \mathrm{m}^{3}$ cathode liquid volume at $48 \mathrm{~mA}$. These values indicate far better performance than the non-catalysed $\mathrm{O}_{2}$ cathode, where at $\mathrm{pH} 6.5$ the open circuit potential was $520 \mathrm{mV}$ and the maximum power was $35 \mathrm{~W} / \mathrm{m}^{3}$ cathode liquid volume. In particular, a higher open

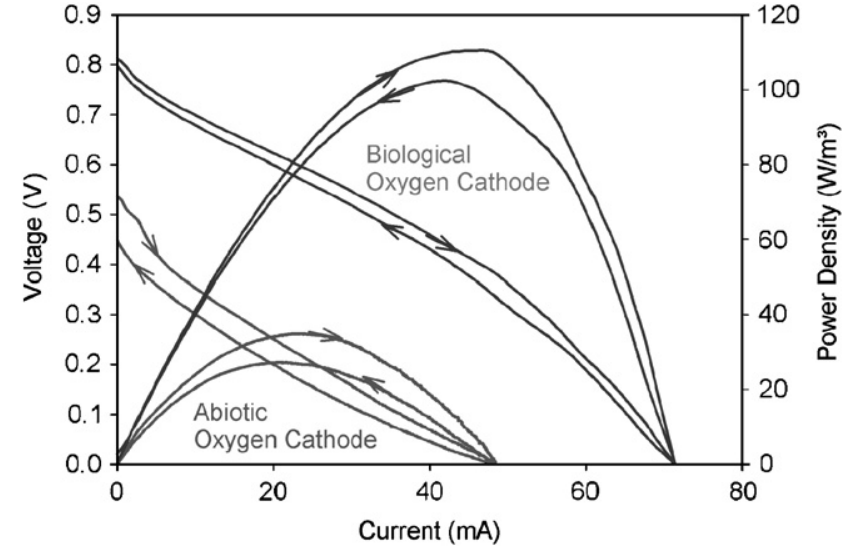

Fig. 3 - Polarization and power curves for an actively aerated sequential anode-cathode MFC fed with acetate at loading rate $3.9 \mathrm{~kg}$ CoD $/ / \mathrm{m}^{3} \mathrm{~d}$; the curves generated with a control abiotic cathode (Freguia et al., 2007a) are also shown.

circuit potential indicates an improved catalysis at the cathode: a reduction of the overpotential at open circuit is related to an increased exchange current density $i_{0}$, which is the outcome of a better catalysis.

\subsection{Cathodic reduction kinetics}

As the cathodic potential was continuously recorded during the generation of the polarization curve, Tafel plots could be generated for the cathode by plotting $\ln (i)$ as a function of the overpotential $\eta=E_{\mathrm{C}, \mathrm{OC}}-E_{\mathrm{C}}$ (where $i$ is the current density in $\mathrm{mA} / \mathrm{m}^{2}$ and $E_{\mathrm{C}, \mathrm{OC}}$ is the open circuit cathodic potential in $\mathrm{V}$ ). The Tafel equation (Eq. (4)) is a linearization of the ButlerVolmer equation valid at overpotentials greater than $80 \mathrm{mV}$ (Freguia et al., 2007a). This equation can be used to calculate the kinetic parameters $\beta$ (symmetry factor) and $i_{0}$ (exchange current, $\mathrm{mA} / \mathrm{m}^{2}$ ).

$\ln \left(\frac{i}{i_{0}}\right)=\frac{\beta F \eta_{\text {cathode }}}{R T}$.

As shown in the Tafel plot in Fig. 4, the calculated values are $\beta=0.37$ and $i_{0}=0.0064 \mathrm{~mA} / \mathrm{m}^{2}$ (normalized to the surface area accessible to the bacteria, as defined above). The same parameters calculated for non-catalysed granules at $\mathrm{pH}=6.5$ (Freguia et al., 2007a) gave a similar $\beta$ value (0.32) but lower $i_{0}$ $\left(9.4 \times 10^{-4} \mathrm{~mA} / \mathrm{m}^{2}\right.$, normalized to the total surface area), indicating that the activation energy for the cathodic reduction was significantly reduced by the development of the cathodic bio-catalysis.

\subsection{Electron balances}

Electron balances at the cathode were calculated as described above to ascertain that oxygen reduction to water fully represented the cathodic process. Table 2 details the result of the balance test on an MFC (MFC-1) run with acetate at the loading of $1.7 \mathrm{~kg}$ COD $/ \mathrm{m}^{3} \mathrm{~d}$ and at an external resistance of $10 \Omega$. The errors were calculated by dividing the equation residuals by $\triangle \mathrm{Ac}_{\mathrm{A}}$ for the anode balance and by OUR for the cathode balance. The errors were $10.2 \%$ at the anode and $17.6 \%$ at the 


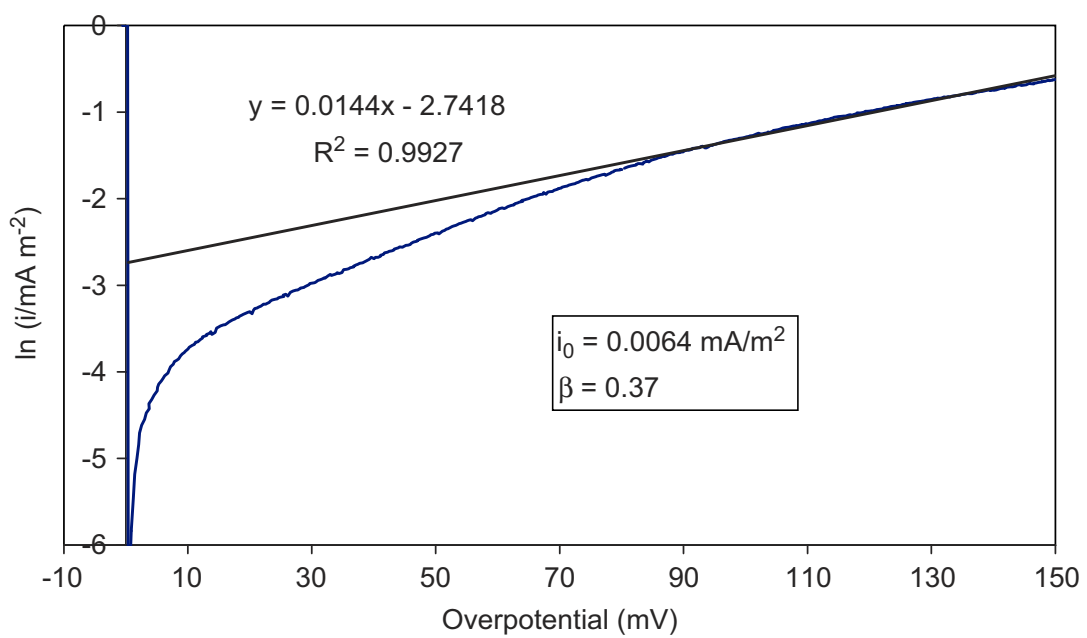

Fig. 4 - Tafel plot for the sequential anode-cathode MFC cathode. The surface area for current density calculation was taken as the surface area accessible to bacteria (the fraction of surface area given by pores larger than $0.8 \mu \mathrm{m}, 7.11 \times 10^{4} \mathrm{~m}^{2} / \mathrm{m}^{3}$ ).

Table 2 - Breakdown of anode and cathode electron balances for a continuous sequential anode-cathode MFC fed with acetate at loading $1.7 \mathrm{kgcoD} / \mathrm{m}^{3} \mathrm{~d}$ and external resistance of $10 \mathrm{Ohm}$ (values \pm standard deviations)

\begin{tabular}{|c|c|c|c|c|c|}
\hline & $\begin{array}{c}\text { Acetate } \\
\text { consumption } \\
8 \Delta \mathrm{Ac}\left(\mathrm{mmole} \mathrm{e}^{-} / \mathrm{h}\right)\end{array}$ & $\begin{array}{c}\text { Current } \\
\frac{3600 \mathrm{I}}{\mathrm{F}}\left(\mathrm{mmol} \mathrm{e}^{-} / \mathrm{h}\right)\end{array}$ & $\begin{array}{l}\text { Bacterial } \\
\text { Growth } \\
\text { 8Y } \Delta \mathrm{Ac} \\
(\mathrm{mmole} / \mathrm{h})\end{array}$ & $\begin{array}{c}\text { Oxygen } \\
\text { reduction } \\
4 \text { OUR } \\
\left(\mathrm{mmol} \mathrm{e}^{-} / \mathrm{h}\right)\end{array}$ & Error (\%) \\
\hline $\begin{array}{l}\text { Cathode electron } \\
\text { balance }\end{array}$ & $0.31 \pm 0.01$ & $1.11 \pm 0.005$ & $0.16 \pm 0.01$ & $1.52 \pm 0.16$ & $17.6 \pm 0.1$ \\
\hline $\begin{array}{l}\text { Anode electron } \\
\text { balance }\end{array}$ & $1.48 \pm 0.02$ & $1.11 \pm 0.005$ & $0.22 \pm 0.003$ & 0.0 & $10.2 \pm 1.5$ \\
\hline
\end{tabular}

cathode. It should be noted that this result is not very sensitive to the selection of a particular value for the cathodic heterotrophic growth yield $\mathrm{Y}_{\mathrm{c}, \mathrm{h}}$ : for a range of 0.3-0.7 $\mathrm{gCOD}_{\text {biomass }} / \mathrm{gCOD}_{\text {acetate, }}$ the errors on anode and cathode balances would range $5-14 \%$ and $13-21 \%$, respectively. This result indicates that no other processes were occurring at significant rates in this system. At the cathode, the electron consumption by $\mathrm{O}_{2}$ reduction was consistently larger than the total electron supply from current and acetate consumption at the cathode. This error could have been caused by hydrolysis and oxidation at the cathode of nonsoluble or slowly biodegradable COD (such as washed-out biomass or lysis products) carried over from the anode, as suggested by the results of the COD analyses reported in Table 1. The small error on the anodic electron balance further proves that $\mathrm{O}_{2}$ does not appreciably diffuse across the Ultrex CEM.

\subsection{Performance of MFCs with trickling bed cathode}

Direct air sparging was useful to close electron balances and to prove the process. However, this is not the preferred aeration mode in a real application as aeration consumes large amounts of energy $\left(0.5 \mathrm{~kW} / \mathrm{m}^{3}\right.$ of treated wastewater in an activated sludge plant). Passive aeration in open air cathodes has been previously proposed as a means to reduce the power consumption of oxygen cathode MFCs (Liu and
Logan, 2004). In this study, we used the cathode as a granular trickling bed (Fig. 1B). Recirculation of the catholyte over the bed was necessary to maintain the granules wet and thus guarantee that cation transfer from CEM to electrode would occur. The performance of this trickling bed sequential anode-cathode MFC was evaluated with polarization curves generated during continuous operation at the loading rate of $2.0 \mathrm{~kg} \mathrm{COD} / \mathrm{m}^{3} \mathrm{~d}$ (influent COD of $500 \mathrm{mg} / \mathrm{L}$ and influent rate of $28 \mathrm{~mL} / \mathrm{h}$ ). Fig. 5 shows the polarization and power curves (forward only) for this reactor configuration at three recirculation rates $(30,80$ and $120 \mathrm{~mL} / \mathrm{h})$. The performance of this aeration mode is clearly inferior to that of the air-sparged configuration. The internal (Ohmic) resistance of the latter configuration was measured by electrochemical impedance spectroscopy to be approximately $1 \Omega$. The steeper slopes in the polarization curves compared with the forced aeration cathode seem to indicate that the trickling bed cathode configuration is affected by higher internal (Ohmic) resistance. Indeed, the liquid discontinuity at the cathode would increase internal resistance by impairing cation transfer through the catholyte. However, this MFC was able to generate significant amounts of current and power without the need of forced aeration. The effect of recirculation clearly spells the necessity to maintain liquid continuity between granules and CEM as a means to transfer charges between them and to avoid local increases of $\mathrm{pH}$, which would locally reduce the oxygen reduction rates. 


\subsection{Effect of temporary increase of loading conditions}

If too much organic substrate is carried over from the anode to the cathode, there is a risk that the heterotrophic population would grow excessively. As acetate-consuming heterotrophs do not need to be attached to the cathode

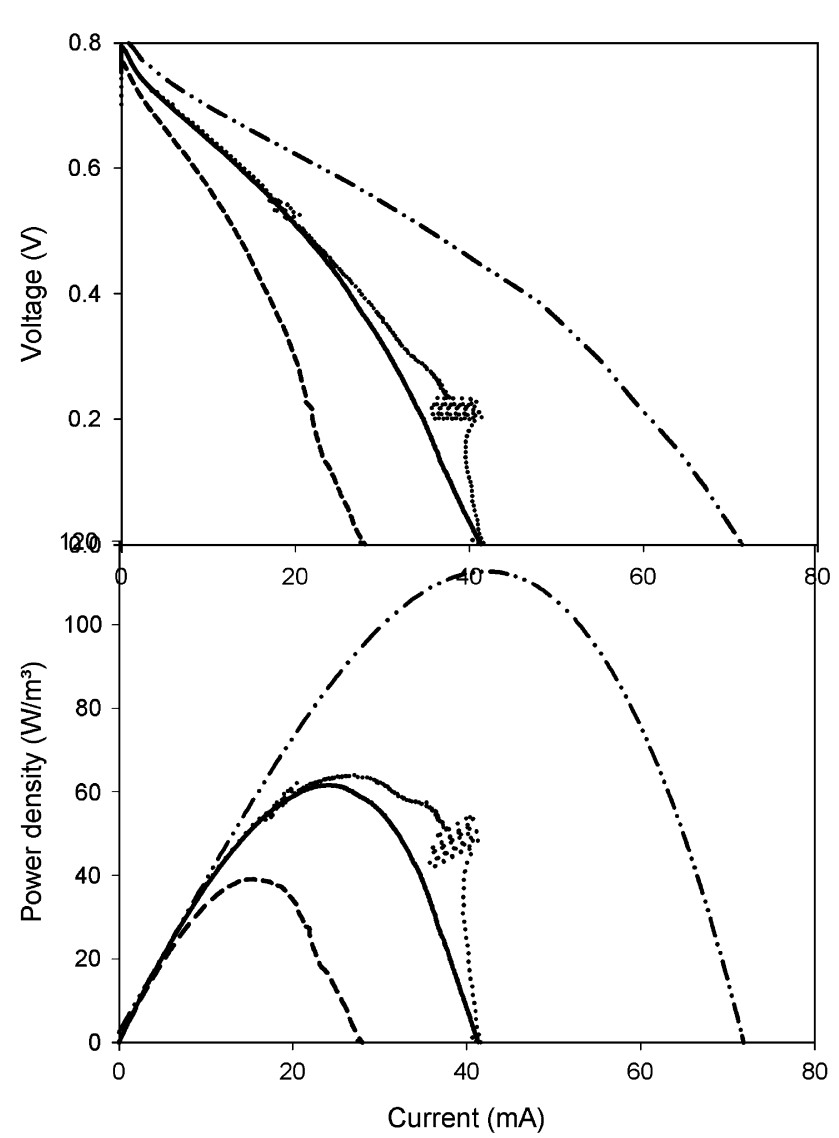

Fig. 5 - Polarization and power curves (forward only) for trickling bed $\mathrm{O}_{2}$ cathode sequential anode-cathode MFC, with $30(--), 80(-), 120(\ldots) \mathrm{mL} / \mathrm{h}$ catholyte recirculation rate. The curves for the active aeration cathode are also shown for reference $(-\cdots)$. surface to survive, they can grow in the outer biofilm, and in this way they can increase mass transfer limitations of $\mathrm{O}_{2}$ to the cathode surface. This would reduce the catalytic activity of the cathode. There is the risk that an excessive organic loading rate may irreversibly turn the cathode into a mere aerobic heterotrophic biofilm. As the cathodic process becomes impaired, less current can be drawn from the anode, causing the anodic process to slow down as well, thus further worsening the problem. Tests were performed to determine the sensitivity of the process to short-term overloaded conditions. A sequential anode-cathode MFC (MFC-1) was run in continuous mode with active aeration over an external resistance of $10 \Omega$. The normal operating condition was a loading of $1.7 \mathrm{~kg} \mathrm{COD} / \mathrm{m}^{3} \mathrm{~d}$. The loading was temporarily doubled for $48 \mathrm{~h}$ (eight hydraulic retention times), by doubling either the influent rate or the influent acetate concentration. The results of this test are reported in Table 3 . The first column represents the standard operating conditions achieved after 2 months of continuous feeding. Upon doubling the feed rate, the current production increased, due to the fact that a higher feed rate allowed for the establishment of a higher $\mathrm{pH}$ at the anode, thus enhancing the activity of the anodophiles (Rabaey et al., 2003). However, more acetate was carried over to the cathode side. The return to the standard feeding conditions (day 4) reduced the performance of the MFC, with a current decrease of $11 \%$ and a Coulombic efficiency reduction of $6 \%$. Doubling the acetate concentration in the feed to $938 \mathrm{mg} / \mathrm{L}$ (day 6) further reduced the current production due to lower anode $\mathrm{pH}$ and high acetate concentration leaving the anode $(688 \mathrm{mg} / \mathrm{L})$, which overloaded the cathode with substrate and increased oxygen consumption for aerobic acetate oxidation. The performance after restoring the standard feed condition was further degraded, with the current 16\% lower and the Coulombic efficiency $18 \%$ lower than the respective initial values. A key performance parameter of the cathodic biofilm is the cathodic potential $\left(E_{c}\right)$. As shown in the tabulated data, the cathodic potential decreased during periods of overfeeding and it was not able to recover to the initial value afterwards, indicating long-term loss of performance. It

Table 3 - Performance of an actively aerated sequential anode-cathode MFC at standard loading conditions (1.7 kgcoD $\left./ \mathrm{m}^{3} \mathrm{~d}\right)$ and high loading conditions $\left(3.4 \mathrm{~kg}_{\mathrm{COD}} / \mathrm{m}^{3} \mathrm{~d}\right) ; 10 \Omega$ external resistance

\begin{tabular}{|c|c|c|c|c|c|}
\hline Conditions & Standard & High feed rate & Standard & High acetate conc. & Standard \\
\hline Time (days) & 0 & 2 & 4 & 6 & 8 \\
\hline Acetate influent $(\mathrm{mg} / \mathrm{L})$ & 469 & 469 & 469 & 938 & 470 \\
\hline Loading (gCoD/L d) & 1.7 & 3.4 & 1.7 & 3.4 & 1.7 \\
\hline Acetate anode $(\mathrm{mg} / \mathrm{L})$ & 118 & 224 & 167 & 688 & 114 \\
\hline Acetate cathode (mg/L) & 8 & 3 & 5 & 6 & 2 \\
\hline Current (mA) & 28.7 & 34.2 & 25.4 & 23.0 & 24.0 \\
\hline Cathodic potential (mV SHE) & +170 & +36 & +114 & +86 & +90 \\
\hline Overall acetate removal (\%) & 98.9 & 99.4 & 99.1 & 99.4 & 99.6 \\
\hline Anodic Coulombic efficiency (\%) & 80 & 64 & 75 & 81 & 66 \\
\hline Energy efficiency $(\%)$ & 14 & 6 & 12 & 5 & 11 \\
\hline pH anode & 6.2 & 6.6 & 6.2 & 6.1 & 6.2 \\
\hline pH cathode & 7.2 & 7.3 & 7.2 & 7.5 & 7.2 \\
\hline
\end{tabular}


appears from this study that short periods of (severe) high loading conditions can have long-term detrimental effects on the performance of the biological cathode. Loading rate control must be used to avoid turning the cathode into an aerobic heterotrophic reactor.

\section{Discussion}

While the ability of graphite granules to carry out cathodic oxygen reduction without a catalyst was described previously (Freguia et al., 2007a), the overall process is still facing serious limitations as the lack of proton selectivity of existing CEMs causes a significant $\mathrm{pH}$ increase in the catholyte. Continuous $\mathrm{pH}$ control would be necessary to maintain the cathode potential, according to Nernst law:

$E_{\mathrm{C}}=E_{\mathrm{C}}^{0}+\frac{R T}{4 \mathrm{~F}} \ln \left(\mathrm{P}_{\mathrm{O}_{2}}\right)-\frac{2.3 R T}{\mathrm{~F}} \mathrm{pH}$,

where $E_{C}$ is the cathode potential, $E_{C}^{0}$ the cathode potential at standard conditions (activities of $\mathrm{O}_{2}$ and $\mathrm{H}^{+}$equal 1 ), $\mathrm{P}_{\mathrm{O}_{2}}$ the partial pressure of $\mathrm{O}_{2}, \mathrm{~T}$ the temperature $(\mathrm{K})$ and $\mathrm{R}$ the ideal gas constant $(8.31 \mathrm{~J} / \mathrm{mol} \mathrm{K})$. Upon connecting anode and cathode hydraulically, the low $\mathrm{pH}$ anode effluent did compensate for the proton consumption at the cathode, thus avoiding the need for $\mathrm{pH}$ control or catholyte replacement. As the overall MFC reaction (Eq. (6)) only consumes one mole of protons per mole of acetate (as sodium acetate was used in the feed), the cathode effluent is just slightly more alkaline than the MFC feed.

$\mathrm{CH}_{3} \mathrm{COO}^{-}+\mathrm{H}^{+}+2 \mathrm{O}_{2} \rightarrow 2 \mathrm{CO}_{2}+2 \mathrm{H}_{2} \mathrm{O}$.

The sequential connection of anode effluent to the cathode allowed for cathode inoculation from biomass that was washed out of the anode compartment. This cross-inoculation would enable the development of two communities of bacteria at the cathode: (1) a community of common aerobic heterotrophs that grow on acetate as electron donor and oxygen as electron acceptor and (2) a community of what we can call cathodophiles (by analogy with anodophiles), i.e. bacteria that catalyse cathodic oxygen reduction to water, either via direct electron transfer from the cathode or through excretion of redox active compounds. The biological pro- cesses happening in this sequential anode-cathode MFC are shown schematically in Fig. 6.

\subsection{Advantages of sequential anode-cathode microbial fuel cells}

The sequential anode-cathode configuration for MFCs shows at least three major advantages over previously described configurations. The first advantage is the ability of these MFCs to treat wastewater at varying organic loading $\left(1.7-3.9 \mathrm{~kg} \mathrm{COD} / \mathrm{m}^{3} \mathrm{~d}\right)$ to generate an effluent with consistently very low COD. The high COD removal is achieved because the cathode process acts as an additional aerobic polishing step following the standard anodic treatment. MFC anodes do not have the ability to thoroughly remove slowly biodegradable COD as shown by consistently incomplete COD removals (Liu et al., 2004). By feeding the anode effluent to an aerobic cathode, heterotrophs growing on the cathode can use oxygen to hydrolyse and oxidize slowly biodegradable COD. Tests on real wastewater will be required to verify the ability of the aerobic cathode to thoroughly remove this fraction of the COD.

The second advantage of sequential anode-cathode MFCs is the compensation of the rising catholyte $\mathrm{pH}$. By feeding an anode effluent at low $\mathrm{pH}$ to the cathode, higher cathode performance and effluent $\mathrm{pH}$ control are achieved. So far, all $\mathrm{O}_{2}$-cathode MFCs that used a CEM to separate anode and cathode suffered from continuously increasing cathode $\mathrm{pH}$ due to the diffusion limitations for protons to migrate to the cathode and non-selectivity of the CEM, requiring $\mathrm{pH}$ control or periodic replacement of the catholyte. This problem is critical for scale-up applications, where replacing large quantities of cathodic medium or using large amounts of acid for $\mathrm{pH}$ correction would not be sustainable. The increasing cathode $\mathrm{pH}$ problem has been addressed by others (Liu and Logan, 2004) with the full replacement of the CEM with an open-air cathode pressed on a poly-tetrafluoroethylene diffusion layer. This method has solved the problem by allowing protons to freely diffuse towards the cathode; unfortunately, oxygen can also travel across the diffusion layer and directly react with the substrate, causing a significant decrease of the Coulombic efficiency. Another method to achieve $\mathrm{pH}$ control has been the use of a bipolar

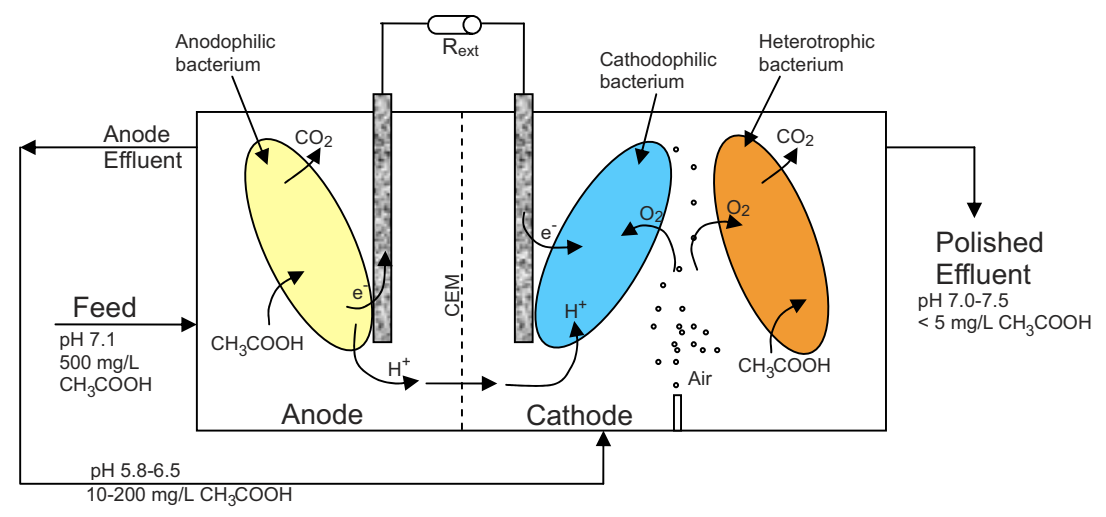

Fig. 6 - Schematic of the biological processes of a sequential anode-cathode microbial fuel cell. 
membrane instead of a CEM (Ter Heijne et al., 2006). While this strategy works to avoid $\mathrm{pH}$ gradients and Coulombic losses, it greatly increases the internal resistance of the MFC. To our knowledge, the sequential anode-cathode configuration presented here is the only feasible method used so far to control the effluent $\mathrm{pH}$ while maintaining high Coulombic efficiency and low MFC internal Ohmic resistance (liquid plus CEM combined electrical resistance), which was determined to be approximately $1 \Omega$ by electrochemical impedance spectroscopy.

The third benefit of sequential anode-cathode MFCs is that they are able to produce four-fold current and three-fold power compared with the non-sequential configurations, likely through the development of a bio-catalyst for cathodic oxygen reduction. So far, research has focused on finding more sustainable and robust catalysts to replace platinum. In sequential anode-cathode MFCs the anode effluent is able to provide the cathode with electrochemically active bacteria and/or biosynthesized compounds that can act as safe and renewable biocatalysts. Moreover, these biocatalysts are not subject to sulphide poisoning, unlike platinum and other metals. If the required water recirculation does not entail high energy costs, achieving cathode catalysis with a biofilm is certainly the most preferable and environmentally friendly solution to the problem of low oxygen reduction rates.

\subsection{Disadvantages of sequential anode-cathode microbial fuel cells}

The main disadvantage of this new configuration is that it requires careful operation to avoid excessive COD entering the cathode. If this was to happen, the growth of aerobic heterotrophs would be increased considerably, which could eventually restrict oxygen supply to the cathodic biofilm and hence prevent electricity generation. Daily monitoring of the anode effluent COD is recommended, and continuous monitoring of the cathodic potential is essential, as its decrease can be a sign of incipient COD carry-over.

A specific requirement of this MFC configuration is also the need for either aeration of the catholyte or liquid recirculation over an open-air cathode in order to provide oxygen to the cathodic biofilm and to maintain liquid continuity between cathode and CEM. Work is underway to solve this limitation with a newly designed open-air cathode where the anode effluent at the top of the cell overflows onto a thin open-air cathode to provide the necessary liquid flow while allowing good aeration of the liquid and cathodic biofilm.

\section{Conclusions}

In this study, continuous oxygen-cathode microbial fuel cells were operated in a new configuration where the anode effluent was used as cathode influent in a sequential anode-cathode fashion. The new configuration resulted in several advantages over conventional MFC designs. In particular, the following improvements are achieved:

- The development of a cathodic biofilm achieves an almost four-fold increase in the fuel cell current compared with an abiotic oxygen cathode and appears to be a sustainable alternative to platinum and other chemical catalysts.

- The aerobic cathode acts as a COD polishing step, due to heterotrophic aerobic biomass growing on the cathode; in this way, the MFC effluent has a low COD concentration, suitable for tertiary treatment or direct discharge to waterways.

- As the combination of anodic and cathodic reactions does not generate or consume significant amounts of protons, this configuration produces an effluent with a $\mathrm{pH}$ which is close to that of the influent; also, it prevents the catholyte $\mathrm{pH}$ from rising too high as typically happens in liquidseparated cathodes.

R E F E R E N C E S

Allen, R.M., Bennetto, H.P., 1993. Microbial fuel-cells-electricity production from carbohydrates. Appl. Biochem. Biotechnol. 39, 27-40.

Bergel, A., Feron, D., Mollica, A., 2005. Catalysis of oxygen reduction in PEM fuel cell by seawater biofilm. Electrochem. Commun. 7 (9), 900-904.

Cheng, S., Liu, H., Logan, B.E., 2006. Power densities using different cathode catalysts (Pt and CoTMPP) and polymer binders (Nafion and PTFE) in single chamber microbial fuel cells. Environ. Sci. Technol. 40 (1), 364-369.

Clauwaert, P., Rabaey, K., Aelterman, P., DeSchamphelaire, L., Pham, T.H., Boeckx, P., Boon, N., Verstraete, W., 2007. Biological denitrification in microbial fuel cells. Environ. Sci. Technol. 41 (9), 3354-3360.

Favas, G., Jackson, W.R., 2003. Hydrothermal dewatering of lower rank coals. 1. Effects of process conditions on the properties of dried product. Fuel 82 (1), 53-57.

Freguia, S., Rabaey, K., Yuan, Z., Keller, J., 2007a. Non-catalyzed cathodic oxygen reduction at graphite granules in microbial fuel cells. Electrochim. Acta. 53 (2), 598-603.

Freguia, S., Rabaey, K., Yuan, Z., Keller, J., 2007b. Electron and carbon balances in microbial fuel cells reveal temporary bacterial storage behavior during electricity generation. Environ. Sci. Technol. 41 (8), 2915-2921.

Greenberg, A., Clesceri, L.S., Eaton, A.D., 1992. Standard Methods for the Examination of Water and Wastewater, 18th ed. American Public Health Association, Washington, DC.

He, Z., Angenent, L.T., 2006. Application of bacterial biocathodes in microbial fuel cells. Electroanalysis 18 (19-20), 2009-2015.

Heijnen, J.J., 1999. Bioenergetics of microbial growth. In: Flickinger, M.C., Drew, S.W. (Eds.), Bioprocess Technology: Fermentation, Biocatalysis, Bioseparation. Wiley, New York, pp. 267-291.

Kim, J.R., Cheng, S., Oh, S.-E., Logan, B.E., 2007. Power generation using different cation, anion, and ultrafiltration membranes in microbial fuel cells. Environ. Sci. Technol. 41 (3), 1004-1009.

Kirchmann, H., Gerzabek, M.H., 1999. Relationship between soil organic matter and micropores in a long-term experiment at Ultuna, Sweden. J. Plant Nutr. Soil Sci. Z. Pflanzenernahrung Bodenkd. 162 (5), 493-498.

Liu, H., Logan, B.E., 2004. Electricity generation using an aircathode single chamber microbial fuel cell in the presence and absence of a proton exchange membrane. Environ. Sci. Technol. 38 (14), 4040-4046.

Liu, H., Ramnarayanan, R., Logan, B.E., 2004. Production of electricity during wastewater treatment using a single chamber microbial fuel cell. Environ. Sci. Technol. 38 (7), 2281-2285.

Logan, B.E., Hamelers, B., Rozendal, R., Schrorder, U., Keller, J., Freguia, S., Aelterman, P., Verstraete, W., Rabaey, K., 2006. 
Microbial fuel cells: methodology and technology. Environ. Sci. Technol. 40 (17), 5181-5192.

Pratt, S., Yuan, Z.G., Gapes, D., Dorigo, M., Zeng, R.J., Keller, J., 2003. Development of a novel titration and off-gas analysis (TOGA) sensor for study of biological processes in wastewater treatment systems. Biotechnol. Bioeng. 81 (4), 482-495.

Rabaey, K., Verstraete, W., 2005. Microbial fuel cells: novel biotechnology for energy generation. Trends Biotechnol 23 (6), 291-298.

Rabaey, K., Lissens, G., Siciliano, S.D., Verstraete, W., 2003. A microbial fuel cell capable of converting glucose to electricity at high rate and efficiency. Biotechnol. Lett. 25 (18), 1531-1535.

Rabaey, K., Ossieur, W., Verhaege, M., Verstraete, W., 2005. Continuous microbial fuel cells convert carbohydrates to electricity. Water Sci. Technol. 52 (1-2), 515-523.
Rozendal, R.A., Hamelers, H.V.M., Buisman, C.J.N., 2006. Effects of membrane cation transport on $\mathrm{pH}$ and microbial fuel cell performance. Environ. Sci. Technol. 40 (17), 5206-5211.

Ter Heijne, A., Hamelers, H.V.M., De Wilde, V., Rozendal, R.A., Buisman, C.J.N., 2006. A bipolar membrane combined with ferric iron reduction as an efficient cathode system in microbial fuel cells. Environ. Sci. Technol. 40 (17), 5200-5205.

Zhao, F., Harnisch, F., Schroder, U., Scholz, F., Bogdanoff, P., Herrmann, I., 2005. Application of pyrolysed iron(II) phthalocyanine and CoTMPP based oxygen reduction catalysts as cathode materials in microbial fuel cells. Electrochem. Commun. 7 (12), 1405-1410.

Zhao, F., Harnisch, F., Schroder, U., Scholz, F., Bogdanoff, P., Herrmann, I., 2006. Challenges and constraints of using oxygen cathodes in microbial fuel cells. Environ. Sci. Technol. 40 (17), 5193-5199. 